\title{
REPATRIATION ADJUSTMENT AND KNOWLEDGE SHARING: A THEORETICAL VIEW
}

\author{
Thasika Yogeswaran, Renusha Vijayakumar, Jasintha Balasubramaniam, \\ Robinson James \\ University of Jaffna, Sri Lanka. \\ thasiyoges@gmail.com,v.renusha@yahoo.com,jasinthabala5@yahoo.com, \\ robinsonj@univ.jfn.ac.lk
}

\begin{abstract}
-
International human resource management (IHRM) literature widely discusses the issues of repatriation of employees in multinational companies. This literature mainly focuses on job related variables and provides theoretical models for repatriation adjustment of corporate employees. However, these models are not sufficient to understand the repatriation process of other repatriates working in different types of organizations. Thus, this study focuses on developing a model that explains causes and consequences of repatriation adjustment of all types of business employees based on existing relevant literature and theories in different field of study. The proposed model was supported by Uncertainty reduction theory socialization tactics theory and cognitive and sense making theory. This model suggests that individual, group and organizational level strategies need to be developed to facilitate repatriation adjustment and the successful repatriation adjustment encourages employees' knowledge sharing intention. Further, it discusses the role of repatriates'personal and situational variables on adjustment. This study contributes to the literature in a way of providing a meaningful theoretical model explaining the factors that facilitate repatriation adjustment and its consequences, and relates socialization theories to repatriation adjustment. This study highlights the role of individual, group and organization in the process of repatriation adjustment and improved (better) use of top talent at the organization.
\end{abstract}

Key words: adjustment, coworker, knowledge sharing, repatriation 


\subsection{Introduction}

In recent years, an increasing number of professionals view international assignments as an opportunity for career development and take steps to acquire such experience with the belief that this will increase their career prospects in their institution as well as in the global job market (Richardson \&Zikic, 2007). For example, universities themselves view academics with international experience as a valuable asset (Welch, 1997, 2005). Providing an expatriate experience to academics is considered a longterm investment by the university. Many organizations invest large amounts of money to provide international experience and to develop their talent pool. The IHRM literature widely discusses the issues of repatriation of employees in multinational companies. This literature mainly focuses on job related variables in relation to repatriation adjustment of business employees at headquarters having completed their assignment at their subsidiary. However, these variables may not be more suitable to understand the repatriation process of other repatriates working in different types of organizations. Thus, this study focuses on developing a model that explains causes and consequences of repatriation adjustment of all types of business employees based on existing relevant literature and theories in different field of study.

\subsection{Theoretical Background}

Theories that explain the socialization process; Uncertainty reduction theory (Berger \& Calabrese, 1975, 1982), soci alization tactics theory (Van Maanen and Schein, 1979), and cognitive and sense making theory (Louis, 1980b) explain how an individual adjusts to a new environment. Socialization tactics theory focuses on the organization's role and the set of tactics that help the new comer to get to know the environment. Uncertainty reduction theory and cognitive and sense making theory focus on the individual's needs for learning to adjust to the new environment. These two theories jointly explain that when individuals enters a new environment, they feel surprised and uncertain. To reduce uncertainty and make sense of the environment, they need to adjust themselves to the environment or adjust the environment to fit them. These two theories highlight both the role of social support and individual proactive behaviour in adjusting to the new environment. Further, the socialization tactics theory clearly states that unsuccessful adjustment leads to newcomer intention to leave the organization. Repatriates' proactive behaviour, perceived social and organizational support influence on repatriation adjustment and repatriation adjustment influence on repatriates' turnover. The organization uses tactics to 
facilitate new members to understand the environment and become an acceptable member of the organization. Successful socialization leads to repatriate's intention to share knowledge.

Socialization tactics can be used to ease the adjustment process when a repatriate returns to their home organization. Both individuals and organizations use tactics to reduce uncertainty and adjust to the new environment. When repatriates experience difficulties adjusting to the new environment it may result in an intention to leave the organization. Socialization Tactics Theory mainly suggests that attempts at the organizational level are needed for repatriates to socialize/adjust to the new environment and unsuccessful adjustment may result in the individual's intention to quit the organization. Uncertainty Theory, and Cognitive and Sense Making Theory explain why and how a repatriate adjusts to a new environment and how individual involvement and social support (co-worker and organization) facilitate this. Active individual involvement in the form of proactive behaviour, together with co-worker support and organizational support, reduces the uncertainty. Repatriates may be reluctant to share their knowledge if they are unable to make sense of their new environment and reduce uncertainty.

\subsection{Literature Review}

\section{Repatriates' proactive behavior and adjustment}

Uncertainty reduction theory and cognitive and sense making theory explain that when an individual enters a new environment, they feel surprised and uncertain. To reduce uncertainty and make sense of the environment, they need to adjust themselves to the environment or adjust the environment to fit them. These two theories argue that uncertainty upon repatriation motivates repatriates to engage in proactive behaviour and by engaging in proactive behaviour, repatriates learn the environment and are able to appropriately adjust through uncertainty reduction and sense making.

Ashford and Black (1996) identified seven types of proactive behavior that individuals can use when they enter into a new organization. These proactive behaviors were: (i) information seeking - searching out information to understand the situation; (ii) feedback seeking - attempting to seek feedback around work performance; (iii) general socializing - developing harmonious relationships with others in the workplace; (iv) building relationship with the boss establishing a valuable relationship with the boss; (v) positive framing - seeing 
the positive side of the situation; (vi) networking - developing ties with others in different parts of the organization; (vii) negotiating - attem-pting to change the job or job demands.

Cooper-Thomas et al. (2012)conducted a study among newcomers (experienced), and identified 19 proactive strategies that they used to socialize to the new environment. This present study identified seven new adjustment strategies: minimizing (doing work that closely matches skills and experience to facilitate performance); proving (working hard to show their talents); giving (providing information or advice to insiders); befriending (being open, friendly, and helpful towards others); teaming (being visibly involved as a team member); exchanging (trading resources with other employees at work); and flattering (behaving in ways that make others feel good about themselves), as newcomer adjustment strategies. Further, proactive behaviors were grouped under three labels: (1) changing role or environment; (2) changing self; (3) mutual development (Cooper-Thomas \& Burke, 2012).

When employees enter into an unfamiliar organization context, to become an accepted member of the organization they engage in a range of proactive behaviors to change themselves, the environment or both. But the choice of proactive behavior, and its consequences, can depend on the context. For example, seeking feedback on job performance can be a more important proactive behavior for a newcomer but less important to academic repatriates, because academic repatriates perform almost the same job before and after their overseas assignment and are well aware of their job and performance measures. Further, in a high powerdistance culture, when newcomers adopt proactive behavior that attempts to change the work role or environment, this may be negatively viewed by their supervisor and co-workers. Such proactive attempts may adversely affect their co-worker support. In a low powerdistance culture this behavior may be positively viewed by others, and the consequences may be positive. In other words, the same proactive behavior may have different consequences in different contexts, and may not lead to expected outcomes (Saks et al., 2011).

In the context of repatriation, repatriates are proactive: they find possibilities to change the context or make use of the context, and attempt to find necessary information for the attainment of personal and organizational goals (DeFillippi \& Arthur, 1994; O'Sullivan 2002). According to O'Sullivan (2002), 
repatriates' proactive behavior can be referred to as repatriates' attempting to gain support in order to achieve positive outcomes. This study defines repatriates' proactive behaviors as repatriates' attempts to change the repatriation context, change themselves or change both in order to better adjust to their repatriation and fit to the organization.

Feldman and Tompson (1993) investigated the relevance of proactive behavior during the career transition of three transition groups: expatriates, repatriates, and domestic geographical relocations. This study analyzed their coping strategies such as information seeking, looking for the positive side of the job, keeping feelings to themselves, refraining from telling their boss about their problems, changing work procedure, and working long hours. Most of these proactive strategies significantly influence the indices of job adjustment, such as general satisfaction, intention to remain and satisfaction with growth opportunities. For example, looking at the positive side of the situation positively influences general satisfaction and intention to remain; changing procedure and working long hours positively influences satisfaction with growth opportunity. Though this study supports the effectiveness of proactive behaviors for better adjustment, the generalizability of this finding to the repatriation population is limited, as the study included only 40 repatriates out of 459 respondents.

The theoretical work of O'Sullivan (2002) focuses on the role of repatriates and their proactive behavior in the process of repatriation adjustment, beyond the organizational responsibility. O'Sullivan suggests that repatriation behaviors such as social networking and information seeking aimed at securing repatriation support are an alternative means to manage repatriation transition, and proactive behavior is needed both before and after the repatriation. The model suggests that proactive personality characteristics that lead to proactive behaviors are the predictors of successful repatriation outcomes. Further, this study proposes that repatriates who engage in proactive repatriation behavior feel more satisfied in their repatriation transition than those who do not engage in proactive behavior. Along with this line of argument Adler's (1981) study found $26 \%$ of repatriates are proactive, proactive repatriates feel satisfied, and quickly adjust to their repatriation. However, Adler's (1981) study did not provide more details about the proactive behaviors repatriates engaged in.

Previous studies highlight that proactive behavior enables repatriates to adjust to 
their repatriation effectively (Adler, 1981; Black et al., 1992; Feldman \& Tompson, 1993). Repatriates engage in proactive behaviour such as job change negotiation, information seeking, networking and positive framing. However these proactive behaviours were more discussed in the literature on repatriation and socialization literature.

\section{Job change negotiation and adjustment}

Repatriates expect a job that better matches their global expertise (Adler, 1981; Black et al., 1992; Hyder \& Lövblad, 2007), but they may be provided a job irrelevant to their expertise (Lazarova \& Cerdin, 2007). There is no empirical evidence to show to what extent repatriates engage in job negotiation and to what extent this proactive behavior facilitates their adjustment. Evidence from the newcomer adjust-ment literature regarding the influence of job change negotiation on adjustment provided mixed results. Gruman et al. (2006) explored that job change negotiation positively linked with adjustment variables such as commitment, task mastery, social interaction, and role clarity, but was not related to the intention to remain, person-organization fit, and job satisfaction. Similarly, Saks et al., (2011) found that job change negotiation was associated with task mastery, role clarity, and social interaction, but not associated with intention to remain, commitment, and satisfaction. Further, Ashford \& Black (1996) found no association either with job satisfaction or performance. The above evidence suggests that though job change negotiation was not directly associated with some adjustment indicators, it facilitates individuals to adjust the new work environment to a certain extent

An irrelevant job creates ambiguity and uncertainty (Black et al., 1992) which may increase the feeling of psychological discomfort at the workplace (Bakker \& Demerouti, 2007). This situation may create as well as increase adjustment challenges and stress (Louis, 1980a, 1980b; Nicholson, 1974; Saks \& Gruman 2012). Individuals attempt to change their environment explicitly to establish control over the environment (Bell \& Staw, 1989) and to best fit with that environment (Cooper-Thomas \& Burke, 2012), and thus individuals are motivated to change to a job that better suits their competency (Nicholson, 1984). Based on theoretical explanations (Nicholson, 1984; Black et at., 1992 Saks et al., 2012; Berger \& Calabrese, 1975) and empirical results on employees' role transition adjustment, we assumed that proactive engagement of repatriates in job change negotiation enables them to adjust to repatriation better. 
Proposition 1: Repatriates' who highly engage in job change negotiation will better adjust to their repatriation transition.

\section{Networking and adjustment}

Networking is an individual's proactive attempt to develop work-related and social ties with others in the organization. Employees with wide and strong networks with others inside and outside of the organization can find more opportunities for career advan-cement. In addition, well-established social ties provide more openings to accumulate more resources for personal and career success (Burt, 1997; Carroll \& Teo, 1996; Tsai \& Ghoshal, 1998). Net working enhances employees' learning and sense making of a complex situation. In the process of organiza tional socialization, newcomers' proa ctive behaviour of networking was positively related to their adjustment (Ashford \& Black, 1996; Gruman et al., 2006; Kim et al., 2005; Saks et al., 2011). The role of networking in the adjustment process of repatriates has been neglected in empirical investi gation. But it is suggested that develo ping networks with others in the organi zation assist repatriates to better adjust to their repatriation (DeFillippi \& Arthur, 1994; O’Sullivan, 2002; Stroh, 1995).
Repatriates need to learn the current work and non-work related norms, values and behaviors (Oddou et al., 2008). Developing networks with others provides chances for more interaction with others; a broad range of interaction helps in learning necessary skills and appropriate workplace behavior (Reichers, 1987), and it provides resource requirements that facilitate adjustment. Further, interaction with others provides meaning to the uncertain situation and increases their satisfaction and the quality of their life, which can enable an individual to achieve a better fit to their organization (Gruman et al., 2006). Thus, repatriates' proactive engagement in networking helps them to learn appropriate work and non-work related behavior that enables them to reduce uncertainty and to adjust to their repatriation better. Based on theoretical explanation and empirical evidence we make the following proposition:

Proposition 2: Repatriates' who highly engage in networking will better adjust to their repatriation transition.

\section{Information seeking and adjustment}

Seeking information is a means of acquiring knowledge about how things work in and around the organization, and what behaviors are expected from a new member in the workplace (Ashford $\&$ Black 1996). Employees try to reduce 
uncertainty during the role transition (Van Mannen \& Schein, 1979), and they seek information to reduce uncertainty to move from an unpredictable to a predictable environment. Information is a critical input to the sense-making process that reduces uncertainty and increases a sense of control (Black et al., 1992; Dervin, 1983; Louis, 1980b; Nicholson 1984; Wilson, 2000).

Dervin (1983) developed the sensemaking approach to explaining information seeking behavior. Sensemaking refers to how an individual makes sense of a situation out of an uncertain context. According to Dervin (1983) information seeking behavior consists of four elements; a situation, a gap, an outcome, and a bridge. The situation refers to the context in which the information need arises. The gap is the difference between the contextual situation and the desired situation. The outcome is the result of understanding the context, and the bridge is closing the gap between the current context and outcomes. This approach suggests that individuals seek information to achieve some goals (Wilson, 2000). When an employee moves from one organization to another organization, the goal of information seeking can be reducing uncertainty and making sense of the new context (Louis, 1980b; Morrison, 2002; Nicholson 1984).
Information enables an individual to reduce uncertainty-related psychological conditions, understand requirements and purpose of a job, and the required nature of relationships with organizational members (Miller \& Jablin, 1991). Information seeking increases learning and reduces uncer tainty (Morrison, 2002). Repatriates may seek different types of information from various sources (Black et al., 1992; O'Sullivan, 2002). Repatriates who received information about their home organization were satisfied with their repatriation (Black et al., 1992). Providing information about expected task performance and expected behavioral patterns in the workplace increases the chance of repatriates developing an accurate expectation that reduces repatriation shock (Adler, 1981; Baughn 1995).Information seeking provides repatriates with control over the environment where they are, and enables them to better adjust to their repatriation. This leads to the next proposition:

Proposition 3: Repatriates who highly engage in information seeking will better adjust to their repatriation transition. 


\section{Organizational support and adjustment}

The literature suggests both expatriates and repatriates suffer during their transition time and upon repatriation expatriates experience more difficulties than their experience on expatriation. Research on expatriation clearly explains that expatriates experience less stress and uncertainty (Muntonet al., 1993) and better adjustment (Kraimer et al., 2001) when they are provided with the necessary organizational assistance and support. A longitudinal study (Takeuchi et al., 2009) on expatriation adjustment found that perceived organizational support was positively associated with both work and general adjustment. Providing appropriate organizational support during the foreign stay and upon repatriation positively influences the adjustment upon repatriation (Black, Gregersen et al., 1992). Howard (1974) emphasizes the role of the organization in minimizing re-entry adjustment difficulties. However the empirical research on the influence of social organizational factors on repatriation adjustment is lacking. Though literature proposes organizational support facili-tate repatriation adjustment, empirical evidence on the direct link between organizational support and repatriation adjustment is lacking. Thus, I propose that:

Proposition 4: Repatriates who perceive high organizational support will better adjust to their repatriation transition.

\section{Co-workers' support and ad- justment}

Repatriates may be perceived wrongly /negatively by their co-workers and treated accordingly. In Japan, repatriates are viewed as outside members and are given a new negative title "kokusaijin" ("an international person"), which infers that the overseas experience infects their original values (Hurn, 1999). Though this issue has not been widely empirically tested, an early study (Gama \& Pedersen, 1977) investigated this issue among Brazilian returnees who returned from their graduate studies in US and found that returnees (University professors) experienced peers' professional jealousy.

Repatriates returning to their home organization where they had been working previously need to undergo a socialization (re-socialization) process which includes learning the process and system, and re-adopting the organization's formal and informal norms and values (Oddou et al., 2008). Through the socialization process repatriates try to understand and acquire the behaviour and attitudes of the organizational members, and become accepted 
members of the group. Repatriates take time to socialize to the norms, values and customs of their home country culture (Sussman, 2000). The literature suggests that this process is usually painful and that support from others can reduce this pain, but that the attitudes and behaviors of organizational members may also make this process very painful and difficult. Peers may fear the repatriates as they feel that these repatriates have bettered themselves and their presence may hinder their own progress or threaten their existing status. Thus they are not ready to accept them. This behavioral issue is common in the organizational setting generally, but repatriates perceive it as a severe problem as they experience various adjustment issues upon their repatriation (Howard, 1974) and in turn this may increase challenges in their process of adjustment. Adler (1981) also found this type of organizational response in regard to accepting new talents and labeled it 'xenophobic' response'. Thus, this study proposes the following hypothesis:

Proposition 5: Repatriates who perceive more co-worker support will better adjust to their repatriation transition.

\section{Individual and situational vari- ables and adjustment}

The influence of age on repatriation adjustment was not clear. Older employees are well aware of the home country context and able to understand the nature of the changes upon their repatriation therefore age has a positive influence on the repatriation adjustment (Black and Gregersen 1991; Black 1994; Cox 2004; Hyder and Lövblad 2007).On the other hand,Suutari and Välimaa (2002)reported that age has a negative influence on adjustment.

Length of time on overseas assignment influences the problems repatriates face upon their repatriation(Harvey 1982). Black, Gregersen et al. (1992) propose that long stay in foreign country influences expectations of repatriates and their adjustments. But the empirical evidence in this regard is inconsistent. While (Black \& Gregersen 1991) reported that length of the period on foreign assignment negatively influences work adjustment but not a general or interaction adjustment. Gregersen and Stroh (1997) Suutari and Välimaa (2002) reported length of time negatively influences on general adjustment but not work or interaction adjustment. However, Gregersen and Stroh (1997) noted that the length of international assignment did not influence on general adjustment. 
Literature suggests that personality characteristics also influence repatriation adjustment. Black, Gregersen et al. (1992, 1999); Vidal et al., (2007) suggest self-efficacy positively influences on repatriation adjustment whereas O'Sullivan (2002) suggests that "Big Five" personality characteristics: extraversion, conscientiousness, openness to experience, emotional stability, or agreeableness influence repatriation transition outcomes through repatriates' protean behaviour. The optimistic repatriates adjust the environment and easily advance in their career (Jassawalla and Sashittal 2011). Therefore, personality characteristics provide different level of energy to cope the repatriation adjustment. Drawing on these arguments, we propose that:

Proposition 6: individual variables such as age, length of overseas stay and personality, influence repatriation adjustment.

\section{Repatriation adjustment \& kno- wledge sharing}

"In the knowledge society, expatriates and repatriates become exporters, importers and local traders of expertise and knowledge, the most precious resource of all" (Inkson et al., 1997, p.355). Repatriates are with a wealth of different kind of knowledge (Lazarova
\& Tarique 2005) and are considered as 'a source of long term competitive advantage' (Downes \& Thomas 1999; Antal 2001). Therefore, knowledge sharing between expatriates, repatriates and organizational members increases global performance of international organizations.

In practice, repatriates experience unsupportive environment upon their repatriation. Repatriates are returning to their home organization with the intention to share their knowledge and contribute to organizational development (Lazarova and Cerdin 2007) but, unsupportive organizational environment makes them feel their knowledge and expertise are completely ignored. Adler (1981) labelled this unsu-pportive environment as "xenophobic response" that prevents the organization from acquiring new knowledge from their repatriates. Also researchers sug-gest organizations fail to make use of repatriates knowledge and experience (Harvey1989), and thus "most companies get anaemic returns on their expat investments" (Black \& Gregersen, 1999, p.53)

The organizational environment and support influence individuals to be motivated to share their knowledge (Adler 1981; Lazarova and Tarique 
2005). Misunderstanding and lack of trust between repatriates and organizational members, unsupportive organizational environment, negative attitudes of organizational members in relation to accepting and valuing repatriates' knowledge negatively affect their knowledge sharing(Oddou, Osland et al. 2008). When repatriates are provided with an appropriate organizational environment that enables them to better adjust to the environment, they are motivated to share their knowledge. Effective repatriation management leads to better utilization of repatriated knowledge (Newton et al., 2007). Also Newton et al. (2007) suggest that repatriation adjustment positively influences repatriates knowledge sharing be haviour.

Inequity perception of repatriates may influence their knowledge sharing behaviour. Adams (1965) found that employees compare their input/output ratios with their co-workers and if there is inequity, they try to reach an equity position by reducing their input or increasing their output. Employees may reduce their input by not employing all the resources they have and reducing their performance level. As repatriates enter into the home organization with a feeling that they have international experience, their knowledge, skill and attitudes are valuable and unique than that of their co-workers, they expect their experience and knowledge to be valued with respect, career advancement opportunities and work autonomy upon their repatriation. In other words they expect more output to equalize their increase input. However, upon their repatriation, if repatriates are not respected or accepted by organizational members (Adler, 1981) and their knowledge and experience are undermined coupled with lack of career development opportunities (Paik, et al. 2002), they might become uncomfortable and experience distress and difficulties to adjust. Therefore, repatriates may feel that though they have more input than others they are not provided with more output than others (inequity) and may reduce their input in the possible and easiest way of not sharing their unique and valuable knowledge to the organizational members in order to maintain equity. This leads to the formulation of the proposition:

Proposition 7: Better repatriation adjustment will result in repatriates' better knowledge sharing

The following model (figure 1) shows the variables that influence repatriation adjustment that result in knowledge sharing.

This study proposes propositions and provides a theoretical model that explains how individual, group and 
organizational level variables influence on repatriate's knowledge sharing behaviour based on both theoretical and empirical evidences. According to this model when repatriates actively engage in proactive behaviour and they perceive co-workers and the organization extending their full support during their repatriation transition they better adjust to their repatriation transition. In addition to this, individual variables such as age, gender, personality and length of overseas stay also influence repatriation adjustment. When repatriates better adjust their repatria-tion they are motivated to share their knowledge.

\section{Figure 1: Repatriation adjustment model}

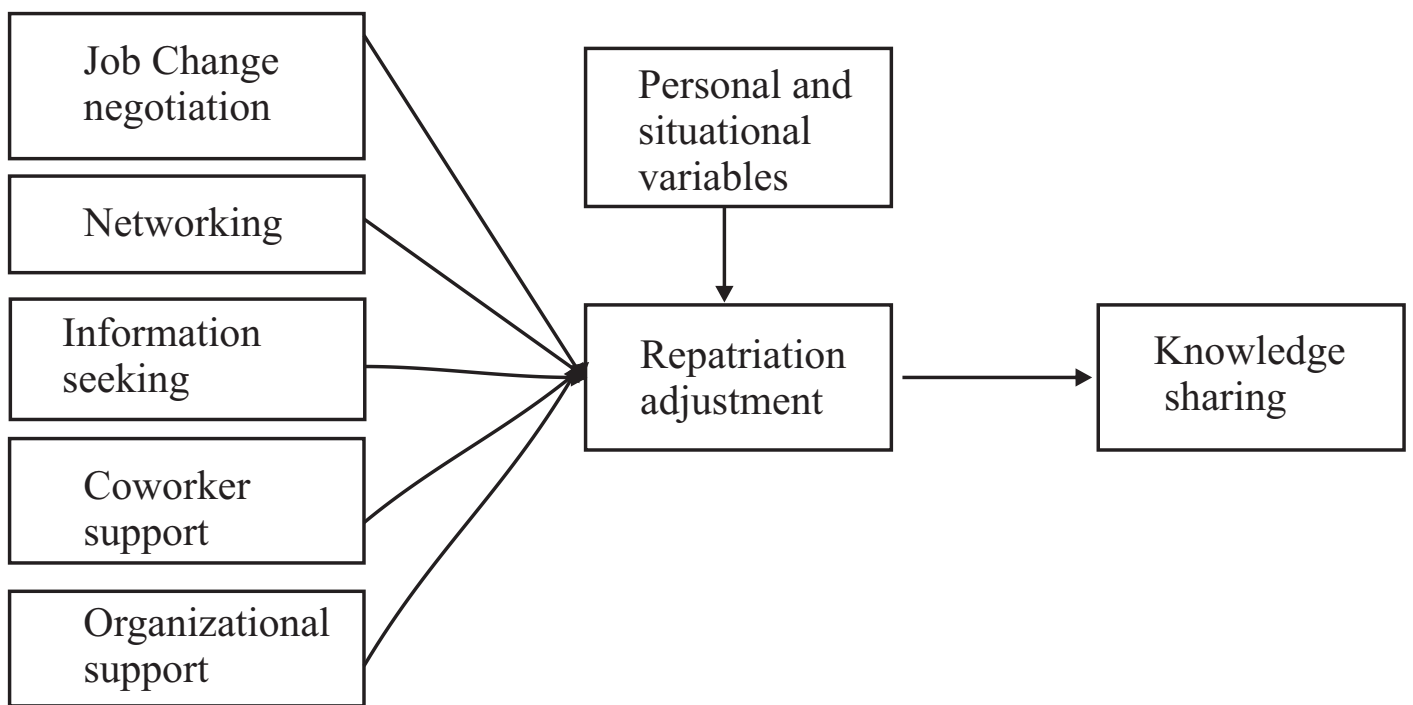

\section{0 conclusion}

This study proposes multilevel effort (individual level, group level and organizational level) that facilitates repatriation adjustment and its consequences. According to uncertainty reduction theory cognitive and sense making theory and organizational socialization theory repatriates' proactive behavior such as job change negotiation, information seeking and networking, co-worker support and organizational support facilitate repatriation adjustment and successful adjustment increase repatriates' intention to share their knowledge.

The proposed model suggests that individuals need to take the necessary steps to overcome the adjustment difficulties. This study provides insights into how repatriates can overcome their repatriation challenges by taking their 
own steps rather than blaming or depending on the organization. In addition to the individual level effort, this study stresses group level and organizational level efforts for better repatriation management. In order to maximize the use of best talent, organizations should provide the necessary support and needs to encourage existing members to support repatriates to enable them adjust to their work and non-work environment. This study provides ideas to the organization for creating an appropriate organizational climate to facilitate repatriation adjustment and provides insights for developing appropriate training programs and adjustment support systems that ease the inevitable adjustment challenges during the repatriation transition period.

Literature on IHRM provides repatriation adjustment models that propose a number of variables closely related to one group of repatriates; repatriates in multinational companies. These variables may not be more suitable to understand the repatriation process of other repatriates other than multinational companies because the organizational environment and purpose of expatriation and repatriation might be different. The model proposed in this study includes the variables suitable for all repatriates of any type of organizations. These variables were drawn from the literature focusing on newcomer adjustment, expatriation and repatriation adjustment of business employees. The proposed relationships among the selected variables were supported by well-developed theories in the field of communication (uncertainty reduction theory) and organizational psychology (organizational socialization and cognitive and sense making theory). Further this model includes the key organizational success variable (knowledge sharing) as an outcome of successful repatriation adjustment. This paper proposed a simple model that provides a foundation for further theoretical and empirical research in this area.

In addition to providing a general model for repatriation adjustment, our research has put forward new questions in need of further investigation. To validate this model further empirical investigation in different cultural contexts are required. To broaden the existing literature in repatriation, researchers need to empirically test this model among different group of repatriates. Further, this study propose that organization and co-worker support facilitate repatriation adjustment; therefore, there is a need for further research to better understand what kinds of organization and coworker support to be provided to facilitate repatriates to better adjust their repatriation transition. 


\section{References}

Adams, J. S. (1965). Inequity in social exchange. In L. Berkowitz (Ed.), Advances in experimental social psychology (pp. 267-299). New York: Academic Press.

Adler, N. J. (1981). Re-entry: Managing cross-cultural transitions. Group \& Organization Management, 6(3), 341-356.

Ashford, S. J., \& Black, J. S. (1996). Proactivity during organizational entry: The role of desire for control. Journal of Applied Psychology, 81(2), 199-214

Bakker, A. B., \& Demerouti, E. (2007). The job demands-resources model: State of the art. Journal of Managerial Psychology, 22(3), 309-328.

Baughn, C. (1995). Personal and organizational factors associated with effective repatriation. In J. Selmer (Ed.), Expatriate management: New ideas for international Business, (pp. 215-230). Westport.

Bell, N. E., \& Staw, B. M. (1989). People as sculptors versus sculpture: the roles of personality and personal control in organizations. In M.B. Arthur, D .T. Hall \& B.S. Lawrence (Eds.), Handbookof career theory (pp. 232-51). Cambridge U, K: Cambridge University Press.

Berger, C. R., \& Bradac, J. J. (1982). Language and social knowledge: Uncertainty in interpersonal relations. London: E. E. Arnold.

Berger, C. R., \& Calabrese, R. J. (1975). Some explorations in initial interaction and beyond: Toward a developmental theory of interpersonal communication. Human communication research, 1(2), 99-112.

Black, J. S., \& Gregersen, H. B. (1991a). Antecedents to cross-cultural adjustment for expatriates in Pacific Rim assignments. Human relations, 44(5), 497-515.

Black, J. S., \& Gregersen, H. B. (1999). So you're coming home. Global Business Pub.

Black, J. S., Gregersen, H. B., \& Mendenhall, M. E. (1992). Toward a theoretical framework of repatriation adjustment. Journal of International Business Studies, 737-760.

Burt, R. S. (1997). A note on social capital and network content. Social Networks, 19(4), 355-373. 
Carroll, G. R., \& Teo, A. C. (1996). On the social networks of managers. Academy of Managementjournal, 39(2), 421-440.

Cooper-Thomas, H. D., \& Burke, S. E. (2012). Newcomer Proactive Behavior: Can There Be Too Much of a Good Thing $\Delta$ In C. Wanberg (Ed.), The Oxford Handbook of Organizational Socialization (pp. 56-77). New York: Oxford University Press Inc

Cox, J. B. (2004). The role of communication, technology, and cultural identity in repatriation adjustment. International Journal of Intercultural Relations, 28(3-4), 201-219.

DeFillippi, R. J., \& Arthur, M. B. (1994). The boundaryless career: A competency-based perspective. Journal of Organizational Behavior, 15(4), 307-324.

Downes, M., \& Thomas, A. S. (1999). Managing overseas assignments to build organizational knowledge. Human Resource Planning, 22(4), 33-47.

Feldman, D. C. (1991). Repatriate moves as career transitions. Human Resource Management Review, 1(3), 163-178.

Gama, E. M. P., \& Pedersen, P. (1977). Readjustment problems of Brazilian returnees from graduate studies in the United States. International Journal of Intercultural Relations, 1(4), 46-59.

Gregersen, H. B., \& Stroh, L. K. (1997). Coming home to the arctic cold: Antecedents to Finnish expatriate and spouse repatriation adjustment. Personnel Psychology, 50(3), 635-654.

Gruman, J. A., Saks, A. M., \& Zweig, D. I. (2006). Organizational socialization tactics and newcomer proactive behaviors: An integrative study. Journal of Vocational Behavior, 69(1), 90-104.

Harvey, M. C. (1982). The other side of foreign assignments: Dealing with the repatriation dilemma. Columbia Journal of World Business, 17(1), 53-59.

Harvey, M. G. (1989). Repatriation of corporate executives: An empirical study. Journal of International Business Studies, 131-144.

Howard, C. G. (1974). The returning overseas executive: Cultural shock in reverse. Human Resource Management, 13(2), 22-26. 
Hurn, B. J. (1999). Repatriation-the toughest assignment of all. Industrial and Commercial Training, 31(6), 224-228.

Hyder, A. S., \& Lövblad, M. (2007). The repatriation process-a realistic approach. Career Development International, 12(3), 264-281.

Inkson, K., Arthur, M. B., Pringle, J., \& Barry, S. (1998). Expatriate assignment versus overseas experience: Contrasting models of international human resource development. Journal of world business, 32(4), 351-368.

Jassawalla, A., \& Sashittal, H. C. (2011). Integrating Repatriated Managers in MNCs. The Role of Expatriates in MNCs Knowledge Mobilization, International Business and Management, 27, 113-130.

Kim, T., Cable, D. M., \& Kim, S. (2005). Socialization tactics, employee proactivity, and person-organization fit. Journal of Applied Psychology, 90(2), 232-241.

Kraimer, M. L., Wayne, S. J., \& Jaworski, R. A. A. (2001). Sources of support and expatriate performance: The mediating role of expatriate adjustment. Personnel Psychology, 54(1), 71-99.

Lazarova, M. B., \& Cerdin, J. L. (2007). Revisiting repatriation concerns: organizational support versus career and contextual influences. Journal of International Business Studies, 38(3), 404-429.

Lazarova, M., \& Tarique, I. (2005). Knowledge transfer upon repatriation. Journal of World Business, 40(4), 361-373.

Louis, M. R. (1980a). Career transitions: Varieties and commonalities. Academy of Management Review, 329-340.

Louis, M. R. (1980b). Surprise and sense making: What newcomers experience in entering unfamiliar organizational settings. Administrative Science Quarterly, 226-251..

Miller, V. D., \& Jablin, F. M. 1991. Information seeking during organizational entry: Influences, tactics and a model of the process. Academy of Management Review, 16: 92-120.

Morrison, E. W. 2002. Newcomers' relationships: The role of social networks during socialization. Academy of Management Journal, 45: 1149-1160

Munton, A. G., Forster, N., Altman, Y., \& Greenbury, L. (1993). Job relocation: Managing people on the move. John Wiley \& Sons. 
Newton, S., Hutchings, K., \& Kabanoff, B. (2007). Repatriation in Australian organisations: Effects of function and value of international assignment on program scope. Asia Pacific Journal of Human Resources, 45(3), 295-313.

Nicholson, N. (1984). A theory of work role transitions. Administrative Science Quarterly, 29(2), 172-191.

O'Sullivan, S. L. (2002). The protean approach to managing repatriation transitions. International Journal of Manpower, 23(7), 597-616.

Oddou, G., Osland, J. S., \& Blakeney, R. N. (2008). Repatriating knowledge: variables influencing the "transfer" process. Journal of International Business Studies, 40(2), 181-199.

Paik, Y., Segaud, B., \& Malinowski, C. (2002). How to improve repatriation management: Are motivations and expectations congruent between the company and expatriates $\Delta$ International Journal of Manpower, 23(7), 635648.

Pattie, M., White, M. M., \& Tansky, J. (2010). The homecoming: a review of support practices for repatriates. Career Development International, 15(4), 359-377.

Reichers, A. E. (1987). An interactionist perspective on newcomersocialization rates. Academy of Management Review, 12(2), 278-287.

Richardson, J., \& Zikic, J. (2007). The darker side of an international academic career. Career Development International, 12(2), 164-186.

Saks, A. M., \& Gruman, J. A. (2012). Getting newcomers on board: A review of socialization practices and introduction to socialization resources theory. In C. Wanberg (Ed.), The Oxford Handbook of Organizational Socialization (pp 27-55). New York: Oxford University Press Inc.

Saks, A. M., Gruman, J. A., \& Cooper-Thomas, H. (2011). The neglected role of proactive behavior and outcomes in newcomer socialization. Journal of Vocational Behavior, 79(1), 36-46.

Stroh, L. K. (1995). Predicting turnover among repatriates: Can organizations affect retention rates $\Delta$ International Journal of Human Resource Management, $6(2), 443-456$.

Sussman, N. M. (2000). The dynamic nature of cultural identity throughout cultural transitions: Why home is not so sweet. Personality and Social Psychology Review, 4(4), 355-373. 
Suutari, V., \& Välimaa, K. (2002). Antecedents of repatriation adjustment: New evidence from Finnish repatriates. International Journal of Manpower, 23(7), 617-634.

Takeuchi, R., Wang, M., Marinova, S. V., \& Yao, X. (2009). Role of domain-specific facets of perceived organizational support during expatriation and implications for performance. Organization Science, 20(3), 621-634.

Tsai, W., \& Ghoshal, S. (1998). Social capital and value creation: The role of intrafirm networks. Academy of management Journal, 41(4), 464-476.

Van Maanen, J., \& Schein, E. H. (1979). Toward a theory of organizational socialization. In B. M. Staw (Ed.), Research for organizational behavior (pp. 209-264). Greenwich, CT: JAI Press.

Vidal, M. E. S., Valle, R. S., \& Aragón, M. I. B. (2007). The adjustment process of Spanish repatriates: A case study. The International Journal of Human Resource Management, 18(8), 1396-1417.

Wang, M. J. (1997). Reentry and reverse culture shock. In Cushner. K., \& Brislin, R.W. (Eds.), Improving intercultural interactions:Modules for Cross-Cultural Training Programs (pp. 109-28). London: Sage, London.

Welch, A. (2005). Challenge and Change: The academic profession in uncertain times. The Professoriate, 1-19.

Welch, A. R. (1997). The peripatetic professor: the internationalisation of the academic profession. Higher Education, 34(3), 323-345.

Wilson, T. D. (2000). Human information behavior. Informing Science, 3(2), 49-56. 